\title{
Using Vark To Increase Student's Structure Ability At English Education Department Madura Islamic University
}

\author{
Samsi Rijal \\ English Education Department, \\ Madura Islamic University
}

Samsirijal83@yahoo.com

\begin{abstract}
This research was conducted based on the researcher's observation at the structure class of the second semester of English Education Department of Madura Islamic University. The result showed that the students' structure scores were very low especially in present perfect subject, it was because of some reasons; 1 ) They felt difficult in understanding the English structures,

2) They did not know how they use present perfect in their daily activities, 3) They were afraid of making mistakes in English structures, 4) They used to study English structures by memorizing the patterns. Concerning with this, the research aimed to solve the students' problems by using VARK (Visual, Auditory, Read/Write, and Kinesthetic) which was developed by Neil Fleming in 1987. The research design was classroom action research (CAR). It was conducted in cycles with the phases of plan of action, the implementation, observation and reflection. The result of this research showed that VARK can solve the problems and improved the students' structure ability. The data showed that before using VARK there was 37.5 $\%$ students who passed the target score. In the cycle 1 , the score of students' structure ability increased, it was

$66.66 \%$ students. The cycle 2 , the score became $83.33 \%$ students could pass the target score. Based on the researcher's data, it can be concluded that using VARK is very effective to improve the students' structure ability.
\end{abstract}

\section{Keywords-VARK, Structure}

\section{INTRODUCTION}

This research comes from the student's problem at the second semester of English Education Department, Teacher Training and Education Faculty, Madura Islamic University in understanding the pattern or the structures of English language. The researcher realized that problem appears because English language still becomes a foreign language for them. Based on the observation was conducted at preliminary study, the researcher found some problems; 1) They felt difficult in understanding English structures, 2) They did not how they use present perfect in their daily activities, 3) They were afraid of making mistakes in English structures, 4) They used to study English structures by memorizing the patterns.

Dealing with the statement above, the researcher tried to implement a strategy to solve the students' structure ability through VARK (Visual, Auditory, Read/Write, and Kinesthetic) that was developed by Neil Fleming in 1987. This strategy is used to know someone's preference in learning process, visual, auditory, and kinesthetic reference The first is visual, it is for someone or a learner who understands easily about what they learn by using pictures, and he or she also feels easy to remember it. The second is auditory; this strategy is used for learners who prefers learning with listening or reading dialogs. The third is kinesthetic, this strategy is used for students who likes learning by doing.

Based on the statement above, the teacher must combine all of the strategies in teaching and learning process to give more abilities and cover the students' weaknesses in their learnings.

\section{RESEARCH METHOD}

The design of this research was Classroom Action Research (CAR). The researcher considered CAR was very essential for the English teacher to apply it in the classroom since it would be beneficial for the teacher as well as the students in learning. reference [3] stated that the aim of classroom action research is to improve the teacher's quality and give understanding in how to achieve the goal of education. Furthermore, reference [2] stated that classroom action research may increase the teaching ability of teachers and assist them to evaluate the process of teaching. Furthermore, reference [4] stated that it is oriented to solve the problems found in the class by following some procedures and steps that have been set up systematically.

This research has steps which is developed by reference [1]. It is started by indentifying the problem, planning, implementing (VARK), observation, and reflection. 
Fig. 1. Classroom Action Research (Kemmis and Taggart)

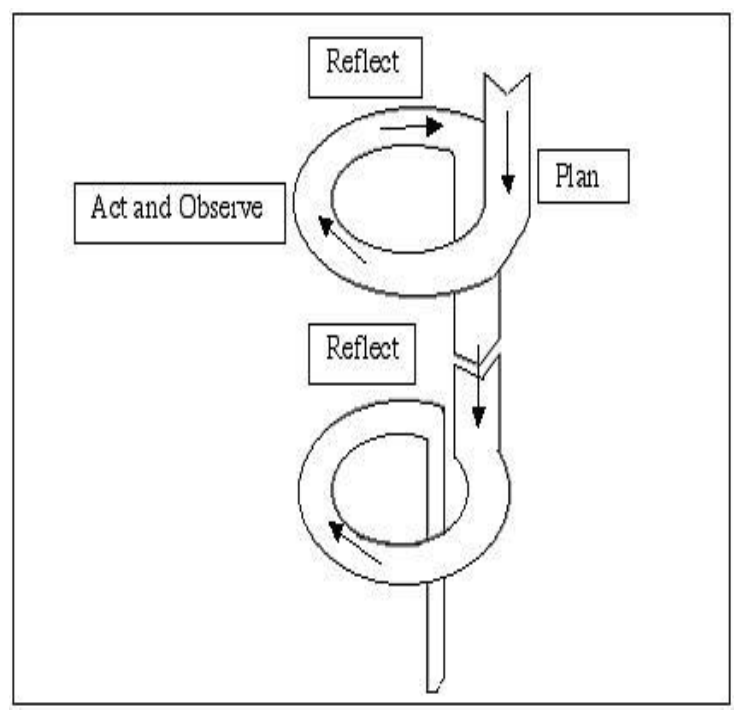

This classroom action research was conducted at the second semester of English education department of Islamic University of Madura in academic year 2016/2017. In collecting the data, the researcher took the data in every cycles. While the data was analyzed, the researcher used descriptive qualitative by looking at the rubric score of structure.

In doing this research, the researcher also made criteria of success to measure the improvement of students' structure ability. The following are the indicator of success:

a. $80 \%$ students get minimum score that is $75(\mathrm{~B})$.

b. Students are active and enjoy the class.

\section{FINDING AND DISCUSSION}

\section{PRELIMINARY STUDY}

The preliminary study was conducted on Thursday, March, $6^{\text {th }}$ 2017. The students asked to answers some questions about structures which is related to the topic.

Based on the result of the preliminary study, the data showed only $37.5 \%$ who got the target score. There were only nine students who derived the score above the Minimum Mastery Criterion. Meanwhile the other 15 students were below the criterion. From that analysis, the result could be seen that almost of the students' structure ability was still very low.

\section{CYCLE I}

\section{Planning}

In this phase, the researcher made a planning for the action based on the problems faced by the students toward structure ability. In this case, the researcher needed to prepare some instruments. The instruments were selected materials which were related to the topic of English structure and also the method of VARK.

\section{Acting}

The cycle 1 was done on March, $13^{\text {th }} 2017$. The researcher implemented the teaching learning process based on the lesson plan had been made. In the first meeting, the action was focused on the observation of the teaching and learning process using VARK. The researcher started with some questions related to the topic, and then the researcher turned on the video to be watched by the students of second semester. While the students watched the video, the researcher sometime paused the video and asked the students to repeat what someone said in the video. After watching the video, the researcher acted some actions and ordered the students to say what he acted. For example, the researcher opened the door, then after opening the door, he asked the students "what has the teacher done?" The Next activity, the researcher pointed one student, and the student answered "you have opened the door". The following activity, the researcher asked the studentsto act an action and the others said what he has done.

\section{Observing}

Based on the observation, the researcher found that teaching and learning process which used VARK was enjoyable and easy to be understood by the students. It can be seen from the students' scores, there was improvements from the preliminary study. In the cycle 1 , the score of students' structure ability increased; it was $66.66 \%$ (16 students who got the target score).

\section{Reflecting}

In the reflecting, the researcher's data were analyzed, evaluated and concluded to judge whether the strategy needs revising or not, the cycle would be quitted if the researcher as well as the students had agreed that the problems had been worked out and the objectives of learning had been achieved. In the other hand, if the strategy did not solve problem, the researcher must see the weaknesses of the action, this was the time for the researcher to reflect the action that had been applied before.

Based on the explanation above, the implementation of VARK was success, but it did not achieve the target, it was $85 \%$ of the students who got the target score. So, the researcher decided to continue to the second cycle.

\section{CYCLE II \\ Planning}

In the cycle II, the researcher replaned some instruments to be implemented. In this cycle, the researcher still used the same strategy to increase the students' structure ability through VARK. The researcher developed the materials to be more interesting and easy to be understood.

Acting

The action of cycle II was done on March, $20^{\text {th }} 2017$. In this cycle, there was a little difference with the cycle I. Most of the students were more interested in joining the class because they were so familiar with the technique which the researcher used. Furthermore, the researcher used different videos and materials in the same topic. 


\section{Observing}

Based on the observation that was done during the teaching learning process, there was an improvement score of students' structure ability. In the cycle I, students who got the target score were $66.66 \%$ (16 students who got the target score), but in the cycle II, students who got the target score is $83.33 \%$ (19 students).

\section{Reflecting}

From the data, the researcher could conclude that the implementation of VARK was success. The researcher found some improvements from the students' structure ability and achieved the criteria minimum of this research; it was $80 \%$ students achieved the target score.

\begin{tabular}{|l|l|l|l|}
\hline Student & PS & CYCLE 1 & CYCLE 2 \\
\hline Student 1 & $\mathbf{7 0}$ & $\mathbf{7 5}$ & $\mathbf{8 0}$ \\
\hline Student 2 & $\mathbf{7 0}$ & $\mathbf{8 0}$ & $\mathbf{8 5}$ \\
\hline Student 3 & 60 & 65 & $\mathbf{7 0}$ \\
\hline Student 4 & 65 & $\mathbf{7 5}$ & $\mathbf{8 0}$ \\
\hline Student 5 & 55 & 65 & $\mathbf{7 0}$ \\
\hline Student 6 & $\mathbf{7 0}$ & $\mathbf{7 5}$ & $\mathbf{8 0}$ \\
\hline Student 7 & 50 & 60 & 65 \\
\hline Student 8 & 60 & $\mathbf{7 0}$ & $\mathbf{7 5}$ \\
\hline Student 9 & 60 & $\mathbf{7 0}$ & $\mathbf{7 5}$ \\
\hline Student 10 & 65 & $\mathbf{7 0}$ & $\mathbf{7 5}$ \\
\hline Student 11 & 65 & $\mathbf{7 5}$ & $\mathbf{8 0}$ \\
\hline Student 12 & $\mathbf{7 5}$ & $\mathbf{8 0}$ & $\mathbf{8 5}$ \\
\hline Student 13 & $\mathbf{8 0}$ & $\mathbf{8 0}$ & $\mathbf{8 5}$ \\
\hline Student 14 & 65 & $\mathbf{8 0}$ & $\mathbf{8 0}$ \\
\hline Student 15 & 55 & 60 & 60 \\
\hline Student 16 & 50 & 55 & 60 \\
\hline Student 17 & $\mathbf{7 5}$ & $\mathbf{8 0}$ & $\mathbf{8 0}$ \\
\hline Student 18 & 50 & 60 & 60 \\
\hline Student 19 & 50 & 65 & $\mathbf{7 5}$ \\
\hline Student 20 & $\mathbf{7 5}$ & $\mathbf{8 0}$ & $\mathbf{8 0}$ \\
\hline Student 21 & $\mathbf{7 0}$ & $\mathbf{7 5}$ & $\mathbf{8 0}$ \\
\hline Student 22 & $\mathbf{7 0}$ & $\mathbf{7 0}$ & $\mathbf{7 5}$ \\
\hline Student 23 & 65 & $\mathbf{7 5}$ & $\mathbf{8 0}$ \\
\hline Student 24 & 50 & 55 & 55 \\
\hline AVERAGE & $\mathbf{3 7 . 5} \%$ & $\mathbf{6 6 . 6 6}$ & $\mathbf{8 3 . 3 3}$ \\
\hline
\end{tabular}

Table 1. Score of English Structure at second Semester of English Education Department Madura Islamic University

\section{CONCLUSION}

Based on the result of the implementation of VARK (Visual, Auditory, Read/Write, and Kinesthetic) in increasing the second semester students' structure ability, it can be concluded that the use of VARK to solve the problems and to improve their structure ability run successfully because of the following reasons; 1) There were the improvement score from preliminary $(37.5 \%$ students who passed the target score), 2) In the cycle I, the score of students' structure ability increased, it was $66.66 \%$ students, 3) the cycle II, the score became $83.33 \%$ students could pass the target score, and 4) there were positive responses from the students during the researcher conducted this strategy. They became more active when the researcher implemented it, 5) this strategy also can accommodate the students' preferences or styles in learning structure. So, the researcher could teach the whole students who have auditory, visual, read and kinesthetic style in their learnings.

\section{REFERENCES}

[1] Kemmis, S. \& R. Mc Taggart. The Action Research Planner. Victoria, Australia; Deakin University Press. 1981

[2] Latief, (Eds). Penelitian Tindakan Kelas Pembelajaran bahasa Inggris.Malang. State University of Malang. 2003

[3] Winarso, H.P. Penelitian Tindakan Kelas; Meningkatkan Professionalitas Guru dan Dosen. Malang : UM Press. 2008

[4] Kasabolah, Kasihani, Workshop Penelitian Tindakan Kelas. Malang: Universitas Islam Malang. 2009

[5] Huda, Miftahul. Model-model Pengajaran dan Pembelajaran; Isu-isu Metodis dan Paradigmatis. Yogyakarta. Pustaka Belajar. 2013 